\title{
Shifting ethics: debating the incentive question in organ transplantation
}

Donald Joralemon Smith College, Northampton, Massachusetts, USA

\begin{abstract}
The paper reviews the discussion within transplantation medicine about the organ supply and demand problem. The focus is on the evolution of attitudes toward compensation plans from the early 1980 s to the present. A vehement rejection on ethical grounds of anything but uncompensated donation - once the professional norm - has slowly been replaced by an open debate of plans that offer financial rewards to persons willing to have their organs, or the organs of deceased kin, taken for transplantation. The paper asks how this shift has occurred and what it tells us about the dynamics of bioethical debates, both within professional circles and in wider public arenas.

(Fournal of Medical Ethics 2001;27:30-35)
\end{abstract}

Keywords: Organ transplantation; financial incentives; donation

\section{Staking-out the moral high ground}

In 1983 Dr H Barry Jacobs, a Virginia physician whose medical licence had been revoked after a conviction for Medicare mail-fraud, founded "International Kidney Exchange, Ltd". He sent a brochure to 7,500 American hospitals offering to broker contracts between patients with end-stagerenal-disease (ESRD) and persons willing to sell one kidney. His enterprise never got off the ground, but Dr Jacobs did spark an ethical debate that resulted in hearings before a US congressional committee headed by an ambitious representative from the state of Tennessee, Albert Gore, Jr.

Testifying before Gore's committee (SubCommittee on Investigations and Oversight of the Committee on Science and Technology, US House of Representatives, Ninety-Eighth Congress, November 7, 9, 1983) were physicians, medical ethicists, directors of organ transplantation organisations, and organ recipients. Aside from Dr Jacobs - whose combative style and occasionally odd interventions earned few points with committee members - the only persons to speak in favour of financial incentives to increase the supply of organs for transplantation were Dr Marvin Brams (University of Delaware, College of Urban Affairs and Public Policy) and kidney recipient Peter Dobrovitz. The latter praised Dr Jacobs for suggesting a solution to the shortage of organs "in a most acceptable capitalistic manner"; "people like Dr Jacobs are merely umbrella salesmen in a rainstorm", explained Dobrovitz.
Among the opponents to monetary rewards for organs were representatives from the US Department of Health and Human Services, the American Society of Transplant Surgeons, the American Medical Association, the North American Transplant Coordinator's Organisation, the American Academy of Pediatrics, the National Association of Patients on Hemodialysis and Transplantation, Inc and the National Kidney Foundation. Bioethicists Arthur Caplan, Warren $\mathrm{T}$ Reich and Robert $\mathrm{M}$ Veatch also spoke against financial arrangements for organs. While some of these witnesses indicated their disapproval in mild terms, others chose strong words to communicate their views: "immoral", "abhorrent", "appalled", "morally repugnant and reprehensible", "offensive", "morally and ethically irresponsible".

Mary Ann Engebretsen, who came to the hearings with a daughter in critical need of a liver transplant, put her objection in simple, but eloquent terms: "I just feel that this offends my sense of right and wrong... . God has given you only one body and you should not sell those parts simply because it is yours... . I just feel it is wrong".

The congressional hearings produced Public Law 98-507, "The National Transplantation Act" (1984), which was brought to a vote with an astonishing 90 co-sponsors from both major political parties. The act made it a federal crime to "knowingly acquire, receive, or otherwise transfer any human organ for valuable consideration for use in human transplantation if the transfer affects interstate commerce". In the years following passage, many state legislatures followed the federal government in outlawing monetary transactions related to the acquisition of organs for transplantation. By 1989, 20 other countries, the World Health Organization, and an array of international medical associations related to transplantation had passed similar regulations and declarations. ${ }^{1}$

In short, in the first decade of successful organ transplantations there developed a remarkable ethical consensus around the world that one should not buy or sell human organs, either from living or dead persons. ${ }^{2}$

\section{Redefining the moral high ground}

Flash forward to March 1996. The annual meeting of the US Department of Health and Human Services Division of Transplantation is organised around the theme: "Toward the Year 2000: Concepts and Considerations in the Consent Proc- 
ess" (Washington, DC). In a plenary address Dr Michael Rohr, Director of Transplantation Services, at the Bowman Gray School of Medicine, Duke University, urges a reconsideration of the "ethical objections and legal impediments to financial incentives for organ donation". Professor Lloyd Cohen, who holds degrees in law and economics, offers a panel presentation on a futures market in cadaver organs.

\section{Pennsylvania plan}

Flash further forward to May 5, 1999. Major US news services report that the state of Pennsylvania is about to initiate an experimental plan to pay a "stipend" of $\$ 300$ to the families of organ donors to defray funeral costs. The payment will go directly to a funeral home, not to the relatives, and a board of medical ethicists will monitor the programme for three years to determine if it has the desired effect of increasing donations. ${ }^{4}$ Howard Nathan, a member of the advisory committee recommending the pilot project, insists that it is not about buying and selling organs: "This is about having a voluntary death benefit for a family who gave a gift".

The Pennsylvania plan has received a mixed response. Antonio Benedi, past president of the Transplant Recipients International Organisation (TRIO), called the plan "very dangerous". ${ }^{6} \mathrm{Dr}$ Francis L Delmonico, director of the kidney transplant programme at Massachusetts General Hospital, declared that "society is not prepared to allow for your body to be bought and sold". ${ }^{6}$ An editorial in the Times-Picayune of New Orleans, Louisiana, said: "This is a dangerous direction for organ donations, a step away from altruism toward commerce... . Pennsylvania has taken a wrong turn that other states should not follow". ${ }^{7}$ Representatives from the federal government warned that the plan will require close scrutiny to determine if it violates the 1984 transplantation law.

Speaking in favour of the initiative on behalf of the National Kidney Foundation (NKF) was Dolph Chianchiano (Director of Scientific and Public Policy, NKF): "Our position is that this should be tested to see whether it serves a purpose. We are not talking about a situation where the organ goes to the highest bidder, or that there should be a market for organs. We are talking about a limited, specified amount of money paid to a third party". ${ }^{6}$ The Courier-fournal of Louisville, Kentucky, editorialised that the plan "seems sensible", that "it is worth a try"; "If a small financial incentive increases the number of organs available to save lives, good will have been accomplished". ${ }^{8}$

Dr Charles Miller, a transplant surgeon at $\mathrm{Mt}$ Sinai Medical Center in Manhattan, noted that people have been afraid even to talk about payments, but said: "I think times have changed. I think the organ donor shortage has become so public and so critical that people are beginning to rethink." ${ }^{\prime \prime}$

The shortage to which Miller refers-in the United States an estimated 18,000 to 20,000 additional donated organs would be required to meet current demand ${ }^{9}$ - has certainly encouraged many organisations and individuals to revisit their objection to financial incentives for organ donation. ${ }^{10}$ The idea of "pilot programmes" like Pennsylvania's, which offer small, prescribed rewards to donor families, seem to many an ethical way to proceed. ${ }^{112}$

More aggressive steps toward financial incentives have also been suggested by persons and organisations that once condemned mixing money with organ donation ${ }^{13}$ : thus the Council on Ethical and Judicial Affairs of the American Medical Association proposed a futures market in cadaver organs, ${ }^{14}$ and members of the International Forum for Transplant Ethics recommended lifting the ban on kidney sales from living donors pending better justifications for prohibiting such transactions. ${ }^{15}$

To review, an approach to organ acquisition that was once almost universally condemned by medical professionals engaged in transplantation, medical ethicists, and politicians is now openly debated and, in a compromised version, is soon to be implemented. How has this ethical shift come about? Are doctors and others associated with transplantation medicine leading public reconsideration of ethical positions, or are they merely responding to changing societal attitudes? Alternatively, are transplant professionals walking an ethical plank while the rest of society watches?

\section{Shaping a medical ethics debate}

PRoceEding WITH CAUTION

Medical professionals engaged in organ transplantation in the United States and elsewhere are exceptionally cautious about promoting shifts in public policy that have ethical implications. Although many are impatient with the public's reluctance to donate organs-a reluctance which is reflected in US consent rates from surviving family that are as low as $46 \%{ }^{16}$ - they are also aware that the entire enterprise of transplantation is vulnerable to public opinion. ${ }^{17}$ This is evident, for example, in the preemptive public relations campaigns directed by hospitals that undertake celebrity transplantations (for example, American baseball star, Mickey Mantel, former Pennsylvania governor Robert Casey, actor Larry Hagman, rock star David Crosby), and controversial transplant experiments (for example, Baby Fae and the baboon heart at Loma Linda Hospital).

The caution is also related to the entire medical profession's recognition that it is more susceptible than in the past to public scrutiny and censure. Sensational revelations of ethically questionable experimentation, the threat of malpractice suits, and increasing oversight by medical insurance managers, institutional review boards (IRBs), and ethics committees, have made serious inroads on a medical paternalism that once granted doctors wide latitude in medical decision making. ${ }^{18}$

As a result, proceeding with even a minimal version of financial compensation for donors has required some innovative strategies to reduce the risk of a negative public reaction. These strategies 
tell us a great deal about the role of the medical profession in shaping ethical debates at the high technology end of medicine. Some tactics appear to be completely deliberate, while others reflect the fortuitous impact of debates over which the medical profession exercises minimal control.

\section{Surveying Public OpINION}

Telephone polls, mailed questionnaires and focus groups are favourite techniques for assessing the willingness of the public to entertain ethically sensitive changes to organ transplant policies, such as new approaches to donation and revisions of the rules that govern the allocation of organs. ${ }^{19}$ For example, the United Network for Organ Sharing, (UNOS) the non-profit organisation contracted by the US government to monitor the transplantation waiting list, and the National Kidney Foundation, sponsored a 1990 survey of public attitudes to donor compensation. ${ }^{20}$

This survey showed a nearly even split between those who would favour and those who would oppose some form of compensation. However, a subsequent report of the UNOS Ethics Committee-which is posted on the UNOS website (www.UNOS.org/Resources/bioethics whitepapers_finance. htm)-refers only to the positive responses and notes, optimistically, that younger respondents (under 35 years of age) were more likely to approve of compensation. ${ }^{11}$ This appears not to be just a case of the glass-half-full, I would submit, but could be interpreted as an illustration of how surveys may be used to support the ethical preferences of the transplantation profession, and how they might be used not just to assess, but to sway, public opinion. ${ }^{21}$

\section{Redefining what constitutes a 'moderate' proposal}

Another emerging phenomenon involves a wellknown political process by which the "centre" of a debate shifts as extreme positions are taken on one side or the other. ${ }^{22}$ Outlandish proposals for a fully free market in bodily organs, which have appeared over the past fifteen years in legal and philosophical journals as well as in the popular press, have had the effect of making other proposals seem more moderate by comparison. ${ }^{23}$ For example, when Professor Henry Hansmann suggested that solicitation of contracts for organ sales might target motorcycle gangs because of the actuarial likelihood that members will be brain dead after accidents, he opened political space for plans like Pennsylvania's, which appear relatively innocuous by contrast. ${ }^{24}$

The quote cited above from Dolph Chianchiano of the National Kidney Foundation shows the tactical advantage produced by the redefinition of the debate's extremes. By explicitly differentiating Pennsylvania's plan from those offered by the "free marketeers", he was able to cast the state's initiative in more favourable terms: "a limited, specified amount of money paid to a third party", not "a market for organs". The effect was to reduce the seriousness of the ethical issue involved by distinguishing the plan from those which would seem to raise more serious questions..$^{22}$

Transplant surgeon A S Daar seems to me to have made - knowingly or unknowingly — good use of this strategy when he put forward a plan for "donation with incentive" as a preferable option to "rampant commercialism". ${ }^{25} \mathrm{He}$ even went so far as to extol the "features of moderation" that make his plan more ethically acceptable. The problem is that for those who question whether any commercial alternative is ethical the proper comparison is not to extreme financial plans, but to the existing system based on altruism. By this standard, Daar's proposal is not moderate.

\section{Modifying the 'terms' of the debate}

Daar appears to me to have employed a second tactic to minimise objections to his plan when he used the neologism "rewarded gifting" to describe payments to families that agree to organ removal. By semantically linking the concept of an altruistic gift to the equally positive notion of a reward-the cultural logic here is that good deeds deserve to be rewarded-Daar has side-stepped the harsher and more troublesome fact that he is proposing monetary payments for access to cadaver organs. Changing the "terms" of the debate has the potential of diffusing reactions to the actual substance of the proposal. ${ }^{26}$

It should be noted that proponents of the existing altruism-based system are also capable of semantic inoculations against unpleasant realities. The cliché "gift of life" is the most obvious illustration, but "sharing of self" and "recycling life" are equivalent disguises for the same medical reality: the surgical removal of vital organs from corpses. ${ }^{27}$

There is also a great deal of word-play at work in other approaches to organ acquisition, sometimes using neutral sounding scientific terms rather than common words when proposals are likely to create offence.

Taking organs from "anencephalic neonates" (not "babies" or "infants") before they meet the legal definition of "whole brain" death.

Using "extended donor criteria" to permit harvesting of organs from the elderly and from persons who suffered from some infectious diseases. ${ }^{28}$

Taking advantage of "self-regarding altruism" to give preference on the transplant waiting list to those who, while still healthy, had signed donor cards. ${ }^{29}$

Permitting "controlled donation" (AKA "elective ventilation") from persons who are "awaiting cardiac arrest" (AKA "non-heart-beating donors").$^{30}$

Allowing persons who are "emotionally or nonemotionally related" to donate a kidney. ${ }^{31}$

It would be easy to cite many parallel examples of linguistic obfuscation in the contemporary world. The most obvious are found in the political and 
military spheres (for example, new taxes become "revenue enhancements", civilian war casualties become "collateral damage"). What these have in common with the euphemisms employed in organ transplant debates is the assumption that a potentially unpopular idea can be sold by softening the language used to refer to it. ${ }^{32}$

\section{Maximising public relations}

The entire enterprise of transplant medicine has made a huge investment in public relations strategies to encourage acceptance of organ replacement and to stimulate donorship. This has included: public service announcements on television and radio (sponsored by the "Coalition on Donation"); an emotional documentary film ("The Kindness of Strangers"); a US postal stamp; a Boy Scout merit badge promoting organ donation; volunteer-staffed booths at public events with a ready supply of carefully designed brochures; the national and international "Transplantation Games" (sponsored by the National Kidney Foundation in the US); solicitation of press coverage of poignant transplant stories; web sites, and celebrity appearances at promotional events like "Organ and Tissue Donation Awareness Day".

Proponents of financial incentive plans have yet to stage a major public relations campaign, probably because of the difficulty of selling an idea that has such well-documented opposition. Occasional editorials in major newspapers and mass circulation magazines are exceptions to the less public discussions about market alternatives to altruistic donation that have appeared in medical ethics and legal journals. ${ }^{33}$

The well-orchestrated announcement of Pennsylvania's "stipend" plan, therefore, represents a public relations "coming out" for those who wish to advocate compensation for organs. The tentativeness with which the project was presented-its "pilot" status, the promised oversight by an ethics committee, the small amount of the payment, and the reassurance that the money goes directly to funeral homes-was clearly meant it, seems to me, to reduce the negative publicity that this plan might otherwise have generated. I suspect that PR consultants will urge a more aggressive and positive campaign if any increase in the supply of organs should be reported in the months following implementation of the plan.

The scholarly literature about incentive plans indicates how they might be promoted to the public. Virtually every article arguing in favour of financial incentives begins with a ritual recitation of the statistics of waiting list deaths, always cast in the rhetorically powerful language of "the tragedy of lives unnecessarily lost". Then, connections are drawn to one or more culturally appealing theme(s), such as property rights and individual autonomy. It is not hard to imagine how a talented advertising firm might reshape these debating points into a persuasive PR campaign. Such a cam- paign might even directly adopt the title of a recent pro-compensation article: "Whose Body Is It Anyway?" ${ }^{34}$

\section{Inviting 'public input'}

Another strategy by which changes to transplantation policies are promoted entails the solicitation of public input on recommendations generated by committees at specific medical centers, by officials of state government agencies, or through the committee structures of national organisations. ${ }^{35}$ After these recommendations are published in some restricted media (for example, in the UNOS publication Update), public comment is sought in a variety of ways, including at public fora and "consensus conferences," in small focus-group meetings, and even on the internet. ${ }^{36}$

A good example of this process-not related to financial incentives-was the elaborate procedure that yielded the "University of Pittsburgh Medical Center Policy for the Care of Terminally Ill Patients Who May Become Organ Donors after Death Following the Removal of Life Support" ${ }^{37}$ In common language, the policy facilitates organ donation from patients who do not meet the criteria of "brain death," but whose end is reasonably certain once life support is removed. To reduce the risk of losing the organs to cellular decomposition once blood flow ceases, the removal of life support is done in an operating room where organ procurement surgeons are waiting. This minimises the ischaemic time, the period during which the organ is deprived of blood, and makes successful transplantation more likely from these "non-heart-beating" donors. ${ }^{38}$

The development of the Pittsburgh policy took five years (1987-1992) and involved consultations with six committees that included hospital administrators and trustees, lawyers, physicians, nurses, social workers, ethicists, anaesthesiologists, neurologists, local clergy, businessmen, and civic leaders. $^{39}$ Notwithstanding some negative responses, this new policy seems to have been implemented and emulated quite rapidly. ${ }^{40}$ So-called "non-heartbeating cadaver protocols" are now common in transplant programmes in the United States and in Europe.

The experience with the Pittsburgh policy is likely to serve as a model for future changes to transplantation procedures, including compensation plans. The advantage of soliciting public input is that it provides a democratic cover for the transplantation profession as it struggles to circumvent opposition. Negative responses indicate where the greatest objections are likely to arise and permit the fine-tuning of proposals before they are finalised. Positive responses become a reservoir of evidence to which policy defenders may refer when questions are raised. And the very process of polling can have the additional salutary effect of desensitising public opinion by the simple act of introducing controversial ideas into the public discourse before they are incorporated into policy changes. 


\section{Shifting ethics: debating the incentive question in organ transplantation}

\section{Conclusion}

The above discussion has reviewed ways that members of the transplantation profession and other interested parties seem to me to have sought to bring about a change in the ethical discourse concerning compensation for organs. The care with which advocates are proceeding shows they recognise that the public is not clamouring for a reversal of the prohibition against financial incentives. In fact, their caution reveals their own suspicion that significant opposition awaits.

My view is that this suspicion is well founded. There are still many indications, both in the United States and in other countries, that money and vital organs occupy distinct moral universes for substantial numbers of health professionals and members of the public at large. ${ }^{41} \mathrm{I}$ am among those who believe that the profession will suffer a serious setback if it attempts to bridge these domains.

Donald Foralemon, PhD, is Professor of Anthropology, Department of Anthropology, Smith College, Northampton, Massachusetts, USA.

\section{References and notes}

1 The British law making it a "criminal offence to give or receive money for supplying organs of either a living or dead person" was passed in 1989 after a scandal involving a paid donor from replacement in American society. New York: Oxford University, 1992).

2 There were certainly dissenting voices during this period, especially coming from legal experts and philosophers trained in ethics (see Joralemon D. Organ wars: the battle for body parts. Medical Anthropology Quarterly 1995;9:335-56).

3 Cohen L. Increasing the supply of transplant organs: the virtues of n options market. New York: Springer, 1995. Cohen's proposa calls for contracts with healthy persons for the right to take their organs for transplantation in the event of their death. The
payoff would be to the person's heirs and would be based on a regulated amount per usable organ

4 As of this writing (March 2000), the Pennsylvania plan has not been implemented. According to a physician central to the project, the state "seems to have lost its nerve".

5 Stolberg S. Pennsylvania set to break taboo on rewards for organ donations. The New York Times 1999 May 6: A1.

6 See reference 5: A30.

7 Anonymous. Danger for organ donations [editorial]. TimesPicayune 1999 May 7: B6.

8 Anonymous. Rewarding donation [editorial]. The Courierfournal 1999 May 7: 12A.

9 Metzger RA.Testimony given at hearings before the subcommittee on health and environment of the committee on commerce House of Representatives, 106th Congress, 1st session April 15, 1999: serial no 106-14: 29-31.

10 Caplan AL, Coelho DH, eds. The ethics of organ transplants: the current debate. Amherst, New York: Prometheus Books, 1998:194-5.

11 Nelson EW, Childress JE, Perryman J, Robards V, Rowan A Seely MS, et al. Financial incentives for organ donation: a report of the UNOS ethics committee payment subcommittee. Richmond, Virginia: UNOS, 1993

12 Rothman DJ, Rose E, Awaya T, Cohen B, Daar AS, Dzemeshkevich SL, et al. The Bellagio Task Force report on transplantation, bodily integrity, and the international traffic in organs. Transplantation Proceedings 1997;29:2741. The task force was an interdisciplinary group brought together by the Columbia University College of Physicians and Surgeons.

13 It is not just the idea of financial incentives that has come up for ethical reconsideration in response to the increasingly severe organ shortage. Other plans for increasing the supply of organs that were once considered ethically suspect and/or medically that were once considered ethically suspect and/or medically accepting living donations from convicts; xenotransplantation; expanding the criteria for donors to include older persons who expanding the criteria for donors to include older persons who
suffered from contagious diseases (for example, syphilis); link- ing organ harvesting to the removal of life support for "non-heart-beating donors"; accepting living donations from "living emotionally related" and "living unrelated" donors; and legislative reforms that would permit organ removal unless an objection has been registered ("presumed consent"). Several of these approaches are already a part of transplantation practice in the United States and in other countries.

14 American Medical Association (AMA). Financial incentives for organ procurement: ethical aspects of future contracts for cadaveric organ procurement: ethical aspects of future contracts for cadaveric
donors. Council on Ethical and Judicial Affairs. Archives of Internal Medicine 1995;155:581-9.

15 Radcliffe-Richards J, Daar AS, Guttmann RD, Hoffenberg R, Kennedy I, Lock M, et al. The case for allowing kidney sales. Lancet 1998;351:1950-2.

16 Siminoff LA, Arnold RM, Caplan AL, Virning BA, Seltzer DL. Public policy governing organ and tissue procurement in the United States: results from the National Organ and Tissue Procurement Study. Annals of Internal Medicine 1995;123:353-

17 Internationally, the refusal rate varies considerably. In France, as many as $61 \%$ of families decline requests (Durand-Zaleski I, Non-procurement of transplantable organs in a tertiary care hospital. Transplantation 1996;62:1224-9), while in Spain the rate has been stable at about $25 \%$ for several years (Matesanz R, Miranda B, Felipe C, Fernandez M, Naya MT. The national transplant organisation: donation evolution and transplant activity in Spain. Annals of Transplantation 1996;1:45-56).

18 Beecher HK. Ethics and clinical research. New England fournal of Medicine 1966;274:1354-60. Jones JH. Bad blood: the Tuskegee syphilis experiment [new and expanded ed]. New York: Free Press, 1993.

19 The United States is not alone in generating survey research on ethical issues in organ transplantation. For example, the Japanese were subjected to more than ten national surveys on the issue of brain death and organ transplantation between 1983 and 1992 (Lock M. Displacing suffering: the reconstuc1983 and 1992 (Lock M. Displacing suffering: the reconstruction of death in North America and Japan. Daedalus 1996;125 228). The international journal Transplantation Proceeding publishes much of this research; the Partnership for Organ Donation offers abstracts of many of the American st
website: www.transweb.org/partnership/abstrac.html

20 United Network for Organ Sharing/National Kidney Foundation. Organ donation study: executive summary of a national survey. Richmond, Virginia: National Kidney Foundation, United Network for Organ Sharing, Southeastern Institute of Research, Inc, 1992.

21 Another apparent such use of survey results in the name of promoting financial incentives is what appears to be the selective reporting of polls. For example: Daar AS. Rewarded gifting. Transplantation Proceedings 1992;24:2207-11 cites an internet debate in which a majority of those responding supported financial compensation. He then asserts that this finding "is in keeping with other polls in the past" (page 366; see also Daar AS. Paid organ donation: the gray basket concept. fournal of Medical Ethics 1998;24:365-8). He does not mention Fournal of Medical Ethics $1998 ; 24: 365-8)$. He does not mention
the polls that have found exactly the opposite (for example, Prottas JM. Altruism, motivation, and allocation: giving and using human organs. Fournal of Social Issues 1993;49:137-50; Altshuler JS, Evanisko MJ. Financial incentives for organ
donation: the perspectives of health care professionals. fournal of the American Medical Association 1992;267:2037-8).

22 Part of this section is adapted from an earlier paper (Joralemon D. The ethics of the organ market: Lloyd Cohen and the free marketeers. In: Brodwin P, ed. Biotechnology and culture. Bloomington, Indiana: Indiana University Press, 2000 (in press).

23 See reference $2: 335-6$

24 Hansmann $\mathrm{H}$. The economics and ethics of markets for human organs. Fournal of Health Politics, Policy and Law 1989;14:57-85. 25 See reference 21: 2207-11. Lloyd Cohen, the legal/economic expert who spoke at the 1996 Division of Transplantation Meeting, also took maximum advantage of the tactic in his book-length defence of a futures market in cadaver organs (see reference 3)

26 Additional examples of what appears to be a semantic strategy in the promotion of financial incentives for organs are: transplant surgeon Thomas Peter's proposed "death benefit" (Peters T. Life or death: the issue of payment in cadaveric organ donation. Fournal of the American Medical Association 1991;265: 1302-5), Pennsylvania's "stipend", and UNOS's "encouraged volunteerism"(1993). Among those who have made note of the widespread use of euphemisms is Jeffrey Prottas (see reference 21). 
27 Campbell CS. The selling of organs, the sharing of self. Second Opinion 1993;19:68-80. Simmons JD. Recycling life. North Carolina Medical Society Health Watch 1996;57:153-5.

28 Zembala M, Religa Z, Majewski J, Knapik P, Bahatyrewicz R, Banas S, et al. Extended donor criteria: a possible way to enhance the number of potential heart donors. Annals of Transplantation 1996;1:44-5. Valerius W, Lewis DD. Organ recovery from an 84-year-old donor: a case study. Fournal of Transplant Coordination 1997;7:211-13. There is active debate about the risks entailed for the recipient of organs from these sources. See: Jacobbi LM, McBride VA, Etheredge EE. The risks, benefits, and costs of expanding donor criteria. Transplantation 1995;60:1491-6; Ko WJ, Chu SJ, Lee YH, Lee PH, Lee CJ, 1995;60:1491-6; Ko WJ, Chu SJ, Lee YH, Lee PH, Lee CJ,
Chao SH, et al. Successful prevention of syphilis transmission from a multiple organ donor with serological evidence of syphifrom a multiple organ donor with serological evidence of syphi-
lis. Transplantation Proceedings 1998;30:3667-8; Degawa, lis. Transplantation Proceedings 1998;30:3667-8; Degawa,
Nemoto HT, Uchiyana M, Kozaki K, Matsumo M, Sakurai E, Nemoto HT, Uchiyana M, Kozaki K, Matsumo M, Sakurai E,
et al. Effect of donor age on renal allograft survival. Transplanet al. Effect of donor age on renal allograft survival. Transplan-
tation Proceedings 1998;30:3660-1; Singh AK, Sharma RK, Agarwal S, Avula S, Gupta A, Kumar A, et al. Long term allograft survival in renal transplantation from elderly donors. Transplantation Proceedings 1998;30:3659.

29 Gillon R. On giving preference to prior volunteers when allocating organs for transplantation. fournal of Medical Ethics 1995;21:195-6. Jarvis R. Join the club: a modest proposal to increase availability of donor organs. Fournal of Medical Ethics 1995;21:199-204

30 Controlled donation entails preparatory interventions to preserve organs for transplantation performed on patients who are on life support, but are not dead by the "whole brain" definition. Once permission is secured from next of kin, the patient nition. Once pernission is secured from next of kin, the patient is remo begin to beat in its own Arnold RM, Younger SJ, Schapiro R, and Spicer CM, eds. Procuring organs for transplant: the debate over non-heartbeating cadaver protocols. Baltimore: Johns Hopkins University, 1995. See also: Sainio K. Are non-heartbeating donors really dead? Annals of Medicine 1997;29:437-75. Dunstan GR. The ethics of organ donation. British Medical Bulletin 1997;53:921-39. Baxter RCS. Children and organ donation in the United Kingdom: a literature review. Fournal of Pediatric Nursing 1996; 11:136-41

31 Evidence from India suggests that this concept has quickly become a loophole in legislation prohibiting commercial sale of kidneys. Persons claim an emotional connection to a patient when they are actually engaged in a contract for sale. See: Sing AK, Srivatsava PA, Kumar A. Current status of transplant coordination and organ donation. Transplantation Proceedings 1998;30:3627-8.
32 In an earlier article (see reference 2) I offered an analogy between this linguistic process and the biological effect of immunosuppressants: a semantic suppression of cultural rejection.

33 Epstein RA. Sell your body, save a life. The Wall Street fournal 1998 Apr 16: A22. Krauthammer C. Yes, let's pay for organs. Time 1999;153:100.

34 Andrews L, Nelkin D. Whose body is it anyway? Disputes over body tissues in a biotechnology age. Lancet 1998;351:53-7.

35 For example, UNOS has permanent standing committees on: communications; ethics; finance; histocompatability; kidney and pancreas transplantation; liver and intestinal organ tran plantation; membership and professional standards; mitransplantion; minority affairs; organ procurement organisations; patient affairs paediatric transplantation; thoracic organ transplantation, and

36 A consensus conference brings together a wide variety of interA consensus conference brings together a wide variety of interested parties to debate policy changes. Sometimes they are used to generate proposals for reform, and other times they are
designed to provide feedback on draft reforms already offered designed to provide feed

37 DeJong WJ, Drachman SL, Gortmaker SL, Beasley C, Evanisko MJ, et al. Options for increasing organ donation: the potential role of financial incentives, standardized hospital procedures, and public education to promote family discussion. Milbank Quarterly 1995;73:3627-8. See also reference 22: Prottas JM: $137-50$

38 The maximum ischaemic time before organs deteriorate beyond transplant potential varies, from five hours for hearts to 72 hours for kidneys (Machado N. Using the bodies of the dead: legal, ethical and organisational dimensions of organ transplantation. Aldershot, UK: Ashgate, 1998: 19.)

39 DeVita MA, Snyder JV. Development of the University of Pittsburgh Medical Center policy for the care of terminally ill patients who may become organ donors after death following patients who may become organ donors after death following removal of life support. In: Arnold RA, Younger SJ, Schapiro R, Spicer CM, eds. In procuring organs for

40 Critical views of the Pittsburgh policy are included in a collection of essays originally published in the Kennedy Institute of Ethics fournal (see reference 39). An especially controversial modification of the Pittsburgh procedure undertaken by other medical centres involved the injection of chemicals to preserve organs for transplant before permission was granted by next of kin. This yielded negative reactions as well as the threat of lawsuits (Kolata G. Controversy erupts over organ removals. New York Times 1997 Apr 13: section 1: 28.

41 See reference 37: De Jong WJ, Drachman SL, Gortmaker: $463-$ 79. 